\title{
Horror de existir
}

Sergio Schargel ${ }^{1}$

O tédio me domina.

Me engole.

Me mina.

Me denomina.

Todo dia o mesmo dia,

Mudam as datas, nada muda.

Acorda trabalha dorme acorda trabalha dorme acorda trabalha dorme acorda trabalha Dorme.

Ao menos

A minha babaquice

Não me incomoda.

O inferno são os outros.

Não,

Mais que isso.

O inferno é estar vivo.

O tédio me domina.

Me engole.

Me mina.

Me denomina.

${ }^{1}$ Mestrando em Literatura pela PUC-Rio (PPGLCC). Mestrando em Ciência Política pela UNIRIO (PPGCP). Brasil, Rio de Janeiro, Rio de Janeiro. sergioschargel_maia@hotmail.com. 